\title{
PEMETAAN POTENSI AIRTANAH DI DAS JUWET KABUPATEN GUNUNGKIDUL
}

\author{
Ahmad Cahyadi ${ }^{1}$, Abdur Rofi ${ }^{2}$ dan Rika Harini ${ }^{3}$ \\ ${ }^{1}$ Departemen Geografi Lingkungan, Fakultas Geografi, Universitas Gadjah Mada, ahmadcahyadi@geo.ugm.ac.id \\ ${ }^{2}$ Departemen Geografi Lingkungan, Fakultas Geografi, Universitas Gadjah Mada, abdurrofi@ugm.ac.id \\ ${ }^{3}$ Departemen Geografi Lingkungan, Fakultas Geografi, Universitas Gadjah Mada, rikaharini@ugm.ac.id
}

\begin{abstract}
ABSTRAK
Penelitian ini bertujuan untuk melakukan pemetaan potensi airtanah di Daerah Aliran Sungai Juwet yang terletak di Kabupaten Gunungkidul, daerah Istimewa Yogyakarta. Penelitian dilakukan dengan memanfaatkan karakteristik hidrogeomorfologi wilayah. Hasil analisis menunjukkan bahwa wilayah kajian dapat dibagi menjadi beberapa zona potensi airtanah, yaitu (1) Zona Potensi Airtanah Sedang dengan Hambatan Lereng, (2) Zona Potensi Airtanah Tinggi, (3) Zona Potensi Airtanah Rendah dengan Hambatan Lereng dan Material, dan (4) Zona Potensi Airtanah Sedang dengan Hambatan Material.
\end{abstract}

Kata Kunci: Pemetaan, Potensi, Airtanah, DAS Juwet

Prosiding Seminar Nasional Geografi Lingkungan I, 27 November 2016 di Fakultas Geografi UGM Yogyakarta. Halaman 184 - 190. ISBN 978-979-8786-65-5 


\section{Pendahuluan}

Airtanah merupakan bagian dari sumberdaya air yang banyak dimanfaatkan oleh manusia untuk memenuhi kebutuhan hidupnya [1,2]. Airtanah biasanya memiliki kualitas yang cenderung lebih baik dibandingkan dengan air permukaan karena mengalami penyaringan oleh tanah dan sulitnya tercemar karena tersimpan di dalam akuifer. Penyimpanan dalam akuifer menyebabkan airtanah juga tidak memerlukan transmisi untuk penyaluran [2,3,4]. Hal ini karena airtanah akan melului media akuifer [1].

Daerah Aliran Sungai (DAS) Juwet merupakan salah satu DAS di Kabupaten Gunungkidul yang secara dominan menempati Kecamatan Gedangsari. Sejak ditetapkan sebagai kecamatan sendiri tahun 1995, Kecamatan Gedangsari mulai melakukan pembangunan infrastruktur terutama pada ledok Hargomulya yang merupakan bagian DAS Juwet bagian hulu. Selain itu, perkembangan pariwisata alam yang menawarkan panorama escarpment Baturagung dan gunungapi purba menyebabkan semakin banyaknya kebutuhan akan air bersih.

Salah satu sumber air bersih yang dapat digunakan untuk memenuhi kebutuhan air bersih di DAS Juwet adalah airtanah. Dalam upaya mendukung pembangunan di DAS Juwet, maka perlu direncanakan tata ruang yang memperhatikan potensi sumberdaya alam dan bencana, salah satunya potensi airtanah. Hal ini karena airtanah tidak dapat ditemukan di semua tempat di muka Bumi ini dengan jumlah yang cukup untuk memenuhi kebutuhan manusia [5]. Oleh karena itu, maka pemetaan menjadi sangat penting, sehingga pembangunan yang akan dating tidak menimbulkan masalah baru (misalnya kekurangan sumberdaya air) dan tidak pula menyebabkan kerusakan lingkungan yang parah [6].

Penelitian ini bertujuan untuk melakukan pemetaan sumberdaya airtanah di DAS Juwet. Kajian ini diharapkan dapat digunakan sebagai salah satu pertimbangan dalam pembangunan di lokasi kajian. Kajian ini dapat memberikan pertimbangan terkait dengan ketersediaan sumberdaya airtanah yang sangat bermanfaat untuk mendukung pembangunan dan segala aktivitas dari manusia.

\section{Metode Penelitian}

Penelitian ini dilakukan dengan pendekatan hidrogeomorfologi. Pemetaan potensi airtanah dilakukan dengan unit analisis berupa bentuklahan. Peta bentuklahan disusun berdasarkan data topografi yang diambil dari Peta Rupa Bumi Indonesia skala 1: 25.000 Tahun 2001 terbitan Badan Koordinasi Survei dan Pemetaan Nasional (sekarang Badan Informasi Geospasial/ BIG) lembar Jabung, Cawas dan Wonosari, peta geologi skala 1: 100.000 tahun 1995 terbitan Badan Geologi lembar Yogyakarta dan lembar Surakarta, survei lapangan, kajian pustaka, data bor dan data geofisika.

\section{Hasil dan Pembahasan}

Secara regional, DAS Juwet sangat terkait dengan keberadaan Gunungapi Purba Baturagung (Gambar 1). Material gunungapi masa lampau sangat dominan menyusun wilayah kajian. Meskipun demikian, proses berikutnya yang sangat mempengaruhi kondisi airtanah berupa proses structural berupa pengangkatan material dasar laut dan terjadinya patahan di beberapa tempat. Kedua kondisi ini menjadi pengontrol utama dalam proses pembentukan akuifer yang terdapat di lokasi kajian. 


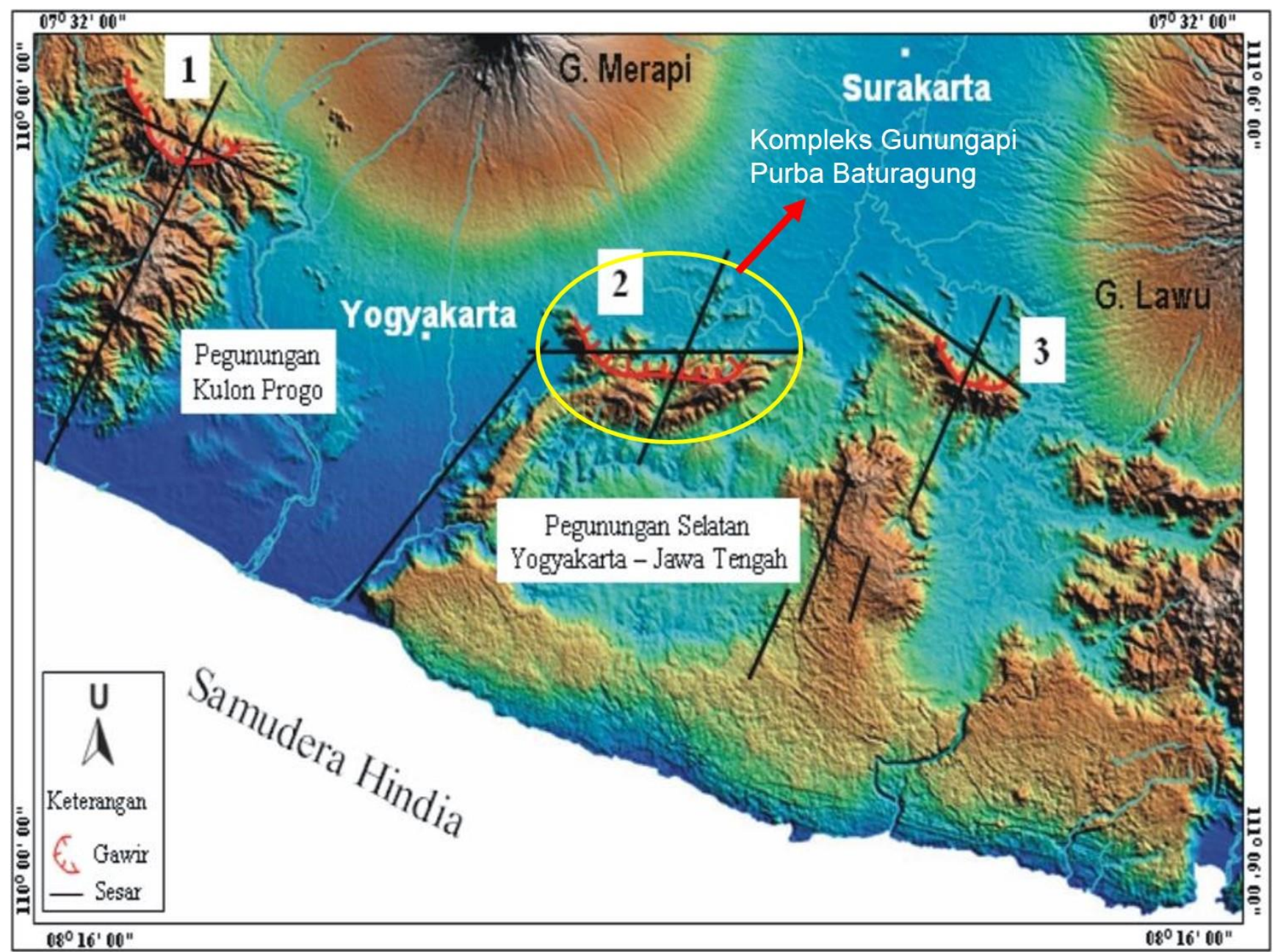

Gambar 1. Kompleks Gunungapi Purba Baturagung [7]

Hasil analisis Peta Geologi Lembar Yogyakarta dan Surakarta pada skala 1:100.000 diketahui bahwa wilayah penelitian terdiri dari lima formasi geologi yaitu Formasi Kebobutak, Formasi Nglanggran, Formasi Semilir, Formasi Sambipitu dan Formasi Wonosari (Gambar 2). Formasi paling tua terdapat di paling utara dan semakin muda ke arah selatan. Peta geologi tersebut juga menun- jukkan bahwa Sungai Juwet berkembang mengikuti jalur patahan mayor dan patahan minor. Patahan utama terdapat di bagian utara DAS Juwet yang membentuk bagian dari Gawir Baturagung, sedangkan patahan minor terletak di tengah dan utara DAS Juwet dan sepanjang sungai berarah utara-selatan. Formasi paling luas adalah Formasi Sambipitu yang meliputi 33,3\% dari luas wilayah (Tabel 1). 


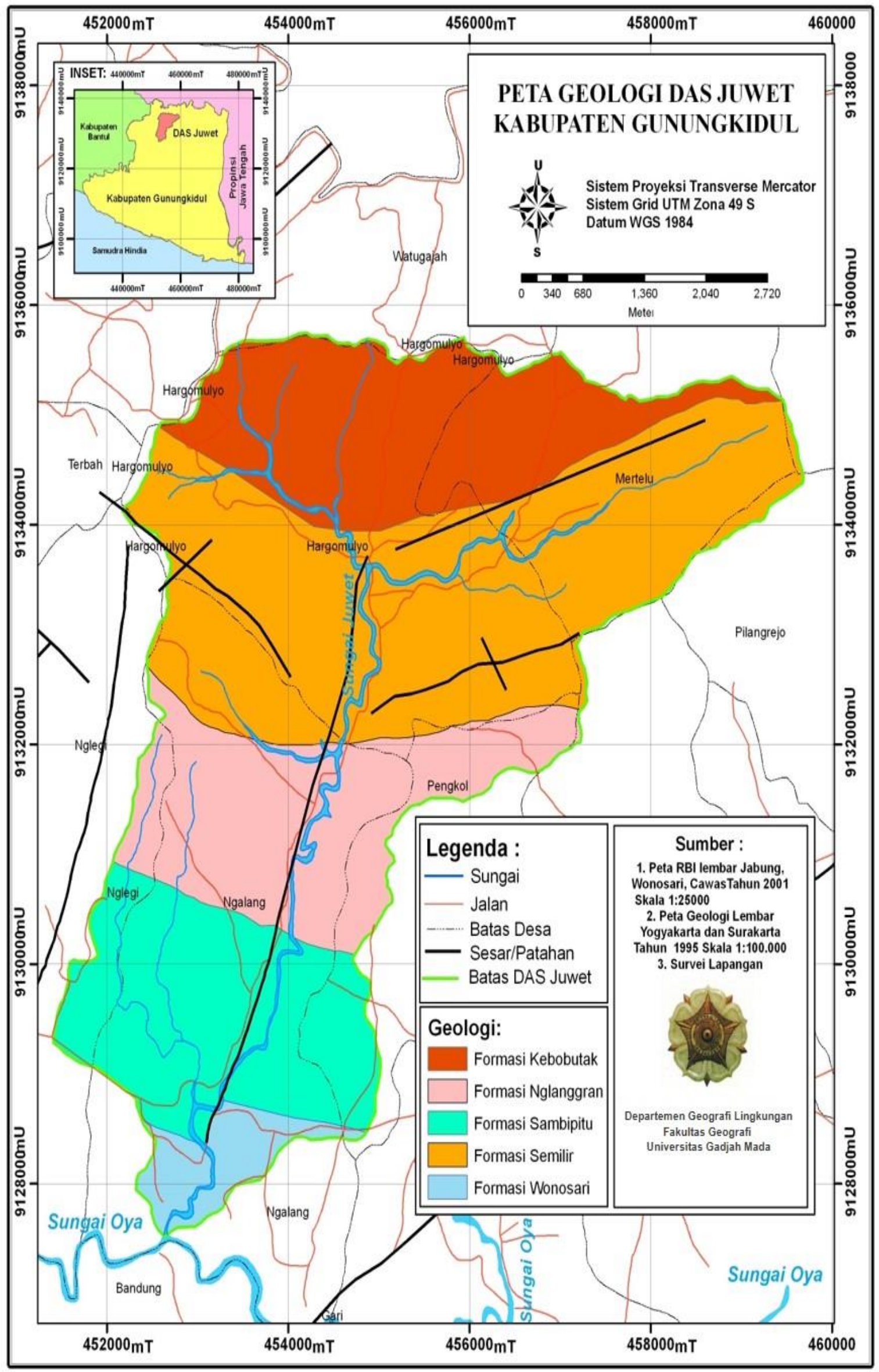

Gambar 4.1. Peta Geologi DAS Juwet

Prosiding Seminar Nasional Geografi Lingkungan I, 27 November 2016 di Fakultas Geografi UGM Yogyakarta. Halaman 184 - 190. ISBN 978-979-8786-65-5 
Tabel 1. Formasi Geologi di DAS Juwet [8]

\begin{tabular}{|l|r|r|}
\hline \multicolumn{1}{|c|}{ Formasi Geologi } & Luas (Ha) & \% Luas \\
\hline Formasi Kebobutak & 779,5 & 23,9 \\
\hline Formasi Nglanggran & 655,9 & 20,1 \\
\hline Formasi Semilir & 516,3 & 15,8 \\
\hline Formasi Sambipitu & $1.086,5$ & 33,3 \\
\hline Formasi Wonosari & 224,9 & 6,9 \\
\hline Jumlah & $3.263,1$ & 100,0 \\
\hline
\end{tabular}

Bentuklahan yang dominan di DAS Juwet adalah bentuklahan structural dengan material utama berupa batuan hasil proses gunungapi masa lampau dan endapan laut masa lampau. Bentuklahan di DAS Juwet terdiri enam bentuklahan (Gambar, 2), yaitu; pegunungan struktural terkikis sedang sampai kuat Formasi Kebobutak, pegunungan struktural terkikis sedang sampai kuat Formasi Semilir, pegunungan struktural terkikis kuat Formasi Nglanggran, Ledok Hargomulyo, lereng kaki pegunungan struktural terkikis sedang Formasi Sambipitu dan lereng kaki pegunungan struktural terkikis ringan Formasi Wonosari [8].

Secara garis besar, wilayah DAS Juwet dapat dibagi menjadi beberapa wilayah berdasarkan kepada potensi airtanahnya (Gambar 3). Pertama, wilayah dengan potensi airtanah sedang dengan hambatan lereng. Wilayah ini secara geologis menempati Formasi Kebo Butak dan Semilir. Wilayah ini terletak di bagian utara dan tengah dari DAS
Juwet yang memiliki lereng lebih dari 25\%. Kemiringan lereng yang tinggi menyebabkan aliran air bergerak dengan lebih cepat meskipun memiliki potensi menyimpan air yang cukup tinggi.

Kedua, wilayah dengan potensi airtanah sedang dengan hambatan material. Wilayah ini memiliki material berupa gamping endapan dan napalan yang menyebabkan kemampuan menyimpan air dan mengalirkan airtanah menjadi lambat. Hal ini menyebabkan potensi imbuhan airtanah dari hujan menjadi sedikit dan potensi pelepasan air dari material menjadi sedikit pula. Wilayah ini terletak di bagian selatan DAS Juwet.

Ketiga, wilayah dengan potensi airtanah rendah dengan hambatan material dan lereng. Wilayah ini menempati wilayah dengan Formasi Nglanggeran dengan batuan gunungapi purba yang kedap air. Hal ini menyebabkan kemampuan menyerap, menyimpan dan mengalirkan airtanah menjadi rendah. 


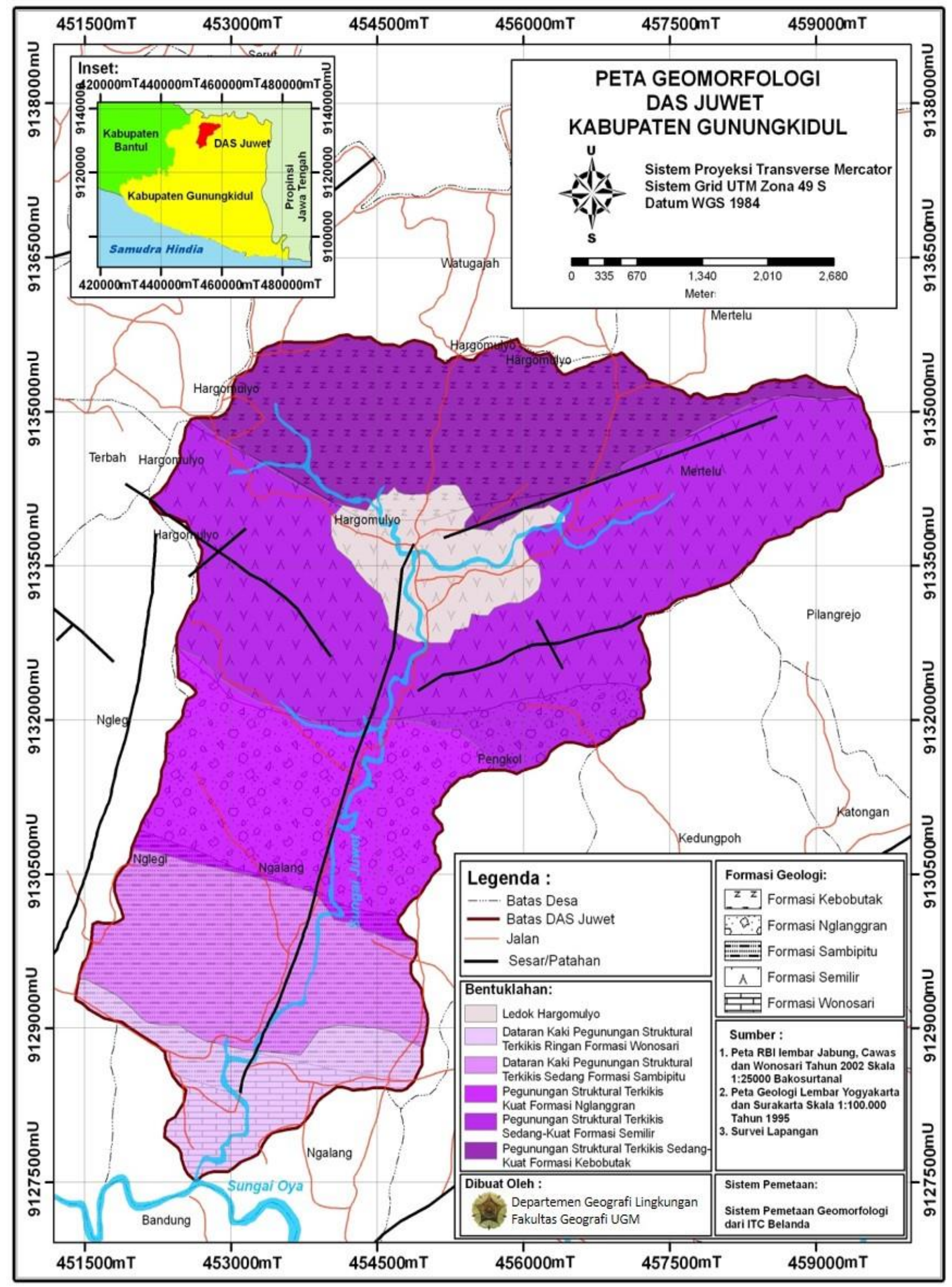

Gambar 2. Peta Geomorfologi DAS Juwet

Prosiding Seminar Nasional Geografi Lingkungan I, 27 November 2016 di Fakultas Geografi UGM Yogyakarta. Halaman 184 - 190. ISBN 978-979-8786-65-5 


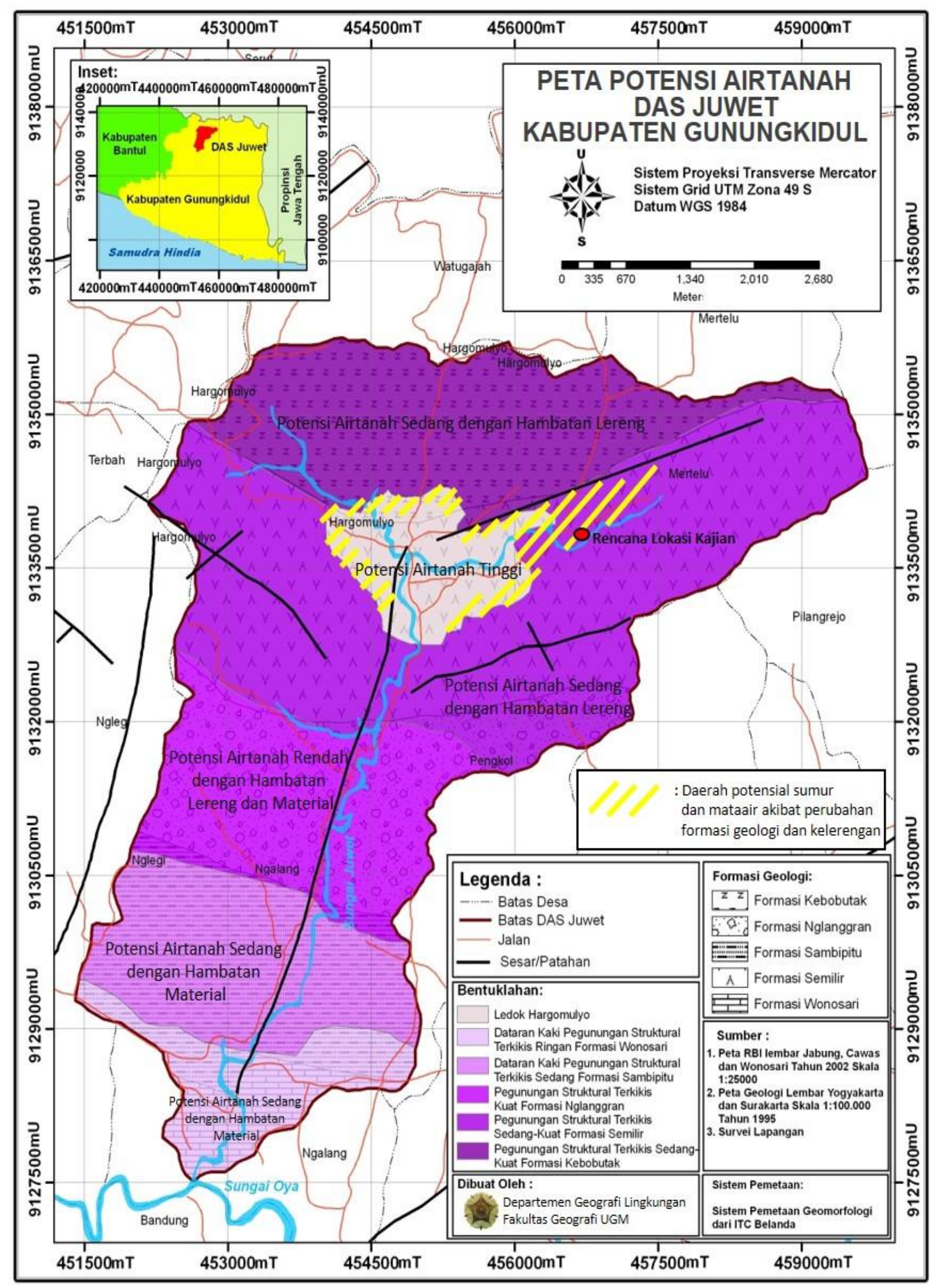

Gambar 3. Peta Potensi Airtanah di DAS Juwet 


\section{Kesimpulan}

Hasil analisis menunjukkan bahwa potenasi airtanah di DAS Juwet sangat dikontrol oleh jenis batuan dan kelerengan. Setidaknya terdapat empat kelompok potensi airtanah, yaitu; (1) Zona Potensi Airtanah Sedang dengan Hambatan Lereng, (2) Zona Potensi Airtanah Tinggi, (3) Zona Potensi Airtanah Rendah dengan Hambatan Lereng dan Material, dan (4) Zona Potensi Airtanah Sedang dengan Hambatan Material.

\section{Pengakuan}

Penelitian ini merupakan bagian dari hibah Program Pengabdian Kepada Masyarakat Berbasis Pemanfaatan Hasil Penelitian dan Penerapan Teknologi Tepat Guna dengan Judul "Optimaslisasi Produksi Pertanian Melalui Metode Pemanenan Air Hujan (Kasus Ledok Hargomulyo, Gedangsari, Kabupaten Gunungkidul)” yang dibiayai oleh Bantuan Pendanaan Perguruan Tinggi Negeri Badan Hukum (BPPTN BH) Universitas Gadjah Mada. Peneliti mengucapkan terimakasih kepada semua pihak yang telah membantu terlaksananya kegiatan penelitian ini.

\section{REFERENSI}

[1] Gilli, E.; Mengan, C. dan Mudry, J. 2012. Hydrogeology: Objectives, Methods, Application. Boca Raton: CRC
Press.

[2] Hoiscock, K.M. 2005. Hydrogeology: Principles and Practice. Malden, USA: Blackwell Pubishing.

[3] Younger, P.L. 2007. Groundwater in the Environment: an Introduction. Malden, USA: Blackwell Pubishing.

[4] Hudak, P.F. 2000. Principles of Hydrogeology. Boca Raton: CRC Press.

[5] Nonner, J.C. 2003. Introduction to Hydrogeology. Tokyo: A.A. Balkema.

[6] Triadmodjo, B. 2009. Hidrologi Terapan. Yogyakarta: Beta Offset.

[7] Bronto, S. dan Hartono, G. 2015. Gunung Api di Pegunungan Kulonprogo, Yogyakarta. Disampaikan dalam Seminar Geologi Pegunungan Kulon Progo tahun 2015. Kampus Lapangan STTNAS Kulonprogo, 14 Maret 2015.

[8] Cahyadi, A. 2012. Kajian Permasalahan Daerah Aliran Sungai Juwet Kabupaten Gunungkidul dan Usulan Penanggulangannya. Makalah dalam Seminar Nasional Informasi Geospasial untuk Kajian Kebencanaan dalam Pelaksanaan Pembangunan Berkelanjutan dan Pengembangan Kecerdasan Spasial Masyarakat, Program Studi Pendidikan Geografi Universitas Sebelas maret, Surakarta, 22 Maret 2012. 